\title{
PENGARUH ORIENTASI SERAT KACA TERHADAP KEKUATAN IMPACT PADA BODI PROTOTIPE MOBIL LISTRIK
}

\author{
Widya Emilia Primaningtyas ${ }^{1}$, Suheni $^{2}$, Irvan Ibrahim ${ }^{3}$ \\ 1,2,3 Jurusan Teknik Mesin, Fakultas Teknologi Industri \\ Institut Teknologi Adhi Tama Surabaya, Jl. Arief Rahman Hakim No.100 Surabaya, 60117 \\ Email : widyaemilia@itats.ac.id
}

\begin{abstract}
The enormous development of electric motor vehicle production has occurred nowadays, become one of the efforts to solve the world energy crisis problem. Study of electric car body made by composite also being improve to reach the car body where lightweight, flexible, affordable, yet have strength and toughness. Research on the effect of orientation variations $\left(30^{\circ}, 45^{\circ}, 60^{\circ}\right.$, and random) of fiber glass on the variation of composition reinforce and matrix (1: 2.7 and 1:4.4) to the impact strength of electric car prototype body is done, and showed the highest impact strength values of variations in the composition of 1: 2.7 with the random orientation fiber glass. For composites with random orientation of fibers with a mixture of composition 1: 2,7 obtain impact strength values of $557.33 \pm 38.68 \mathrm{kgm} / \mathrm{m}^{2}$, while in the composition of 1: 4.4 obtained value only $400 \mathrm{kgm} / \mathrm{m}^{2}$, whereas each of these impact strength values respectively are the highest compared to the other uniform angle composites arrangement in each composition of mixture. Also concluded that the impact strength values will increase with the addition of fiber composition on the composite mixture.
\end{abstract}

Key Word : Fiber Glass, Composite, Orientation, Impact Strength

\begin{abstract}
ABSTRAK
Pengembangan produksi kendaraan bermotor berpenggerak listrik tengah berjalan pesat dewasa ini, sebagai salah satu upaya pemecahan masalah krisis energi dunia. Studi perihal bodi mobil listrik berbahan komposit pun juga sedang dikembangkan untuk mencapai bodi mobil yang ringan, fleksibel, ekonomis, namun kuat dan tangguh. Penelitian tentang pengaruh variasi penyusunan orientasi serat kaca $\left(30^{\circ}, 45^{\circ}, 60^{\circ}\right.$, dan Acak) pada variasi komposisi material penguat dan material pengikat (1:2,7 dan 1:4,4) terhadap kekuatan impact pada bodi mobil listrik tipe prototipe dilakukan, dan didapatkan hasil nilai kekuatan impact tertinggi dari variasi komposisi $1: 2,7$ dengan penyusunan serat gelas secara acak. Untuk komposit dengan susunan serat acak dengan campuran komposisi 1:2,7 didapatkan nilai kekuatan impact sebesar $557.33 \pm 38.68$ $\mathrm{kgm} / \mathrm{m}^{2}$, sedangkan untuk komposisi 1:4,4 didapat nilai $400 \mathrm{kgm} / \mathrm{m}^{2}$, dan masing-masing nilai tersebut merupakan kekuatan impact tertinggi dibandingkan dengan komposit yang tersusun secara seragam dengan variasi sudut di setiap komposisi campuran. Disimpulkan juga bahwa nilai kekuatan impact akan meningkat dengan bertambahnya komposisi penambahan serat pada campuran komposit.
\end{abstract}

Kata Kunci : Serat Gelas, Komposit, Orientasi, Kekuatan Impact

\section{PENDAHULUAN}

Perkembangan era globalisasi berdampak langsung pada kebutuhan konsumsi energi yang semakin meningkat. Nilai konsumsi energi konvensional berbanding terbalik terhadap ketersediaan sumber energinya. Ketidakseimbangan penggunaan energi fosil, eksplorasi sumber energi, bahkan ekploitasi mengakibatkan terjadinya krisis energi dunia. Selain itu, penggunaan energi fosil sebagai energi yang tidak dapat diperbaharui juga berbagai permasalahan lingkungan. Konsumsi energi terbesar saat ini yaitu pada sektor transportasi, dimana sebahagian besar masih bergantung pada energi konvensional. Seiring dengan permasalahan yang sedang berkembang, pengembangan produksi kendaraan bermotor berpenggerak listrik tengah berjalan pesat dewasa ini, sebagai salah satu upaya pemecahan masalah krisis energi dunia. Studi perihal bodi mobil listrik berbahan 
komposit pun juga sedang dikembangkan untuk mencapai bodi mobil yang ringan, fleksibel, ekonomis, namun kuat dan tangguh.

Komposit dikenal sebagai suatu campuran dua komponen atau lebih, yang menghasilkan material baru yang memiliki sifat unggul dari material pembentuknya[1]. Penggunaan material komposit di era ini sangatlah luas di berbagai apliksi teknik, seperti barang-.barang luar angkasa, transportasi laut, dan otomotif, karena komposit memiliki sifat mekanik yang luar biasa, dari segi hubungan antara kekuatan terhadap berat, kekakuan terhadap berat, fomability, dan toleransi kerusakan[2]. Jika dibandingkan dengan material isotropic yang lain, pendekatan prediksi kegagalan material pada komposit bisa dikatakan tidak mudah, hal tersebut dikarenakan beberapa ketidakpastian mengenai hubungan antara geometri mikrostruktur dan sifat mekaniknya[3-5]. Pada kemampuan pembebanan material komposit, ditemukan nilai yang bersifat acak, hal ini disebabkan oleh kompleksitas material akibat sifat anisotropi,sifat heterogen, dan deposit cacat selama proses manufaktur[6,7]. Secara sederhana sifat komposit dituliskan dengan sifat material penyusunnya dalam fraksi volume (sifat matriks $\mathrm{x}$ fraksi volume matriks + sifat penguat $\mathrm{x}$ fraksi volume penguat). Namun kenyataannya tidaklah demikian, karena terdapat berbagai factor factor interaksi antara matriks dengan penguat yang mempengaruhi, atara lain geometri, ukuran, orientasi, dan distribusi penguat juga turut menentukan sifat mekanik suatu komposit[1].

Ketahanan impact adalah salah satu aspek yang berpengaruh besar pada sifat mekanik suatu material aplikatif[8]. Ketahanan pada beban kejut adalah aspek yang cukup dipertimbangkan untuk material komposit serat berlapis, dimana material tersebut pada dasarnya bersifat rapuh, memiliki banyak kecacatan dibawah permukaan seperti delaminasi, retak pada matriks dan patah serat. Kerusakan ini bisa saja hadir bahkan ketika tidak ada efek negative yang langsung nampak pada permukaan lapisan komposit. Adanya beban kejut berpotensi hadir selama penggunaan kendaraan bermotor dalam berbagai bentuk, seperti beban tiba-tiba akibat hantaman batu atau lubang dijalan raya, efek getaran yang dihasilkan oleh mesin dan sistem pengereman terhadap rangka mobil, dan kemungkinan terjadinya kecelakaan. Selain itu, lapisan komposit ini memiliki sifat mekanik yang sangat rendah pada arah yg sejajar ketebalannya. Selain itu, pentingnya mengukur ketahanan beban kejut adalah potensi yang lebih berbahaya yang dihasilkan oleh beban impact rendah yang berulang, karena kontak beban yang berulang dan cukup panjang pada struktur memungkinkan untuk tidak terdeteksi di permukaan tetapi dapat menimbulkan inisiasi retak dibawah permukaan yang dapat menyebabkan kegagalan yang mendadak. durasi kontak cukup panjang untuk seluruh struktur untuk merespon dan dapat memulai retak bawah permukaan terdeteksi yang dapat menyebabkan kegagalan tiba-tiba[9]. Berdasarkan beberapa aspek penentu sifat mekanik komposit yang telah dijelaskan diatas, serta pentingnya pengukuran kekuatan impact sebagai salah satu tolok ukur kekuatan komposit yang akan digunakan untuk bodi mobil listrik tipe prototype maka penelitian ini dilakukan untuk mengetahui nilai kekuatan impact komposit yang tersusun seragam (uniaksial) dengan berbagai variasi sudut penyusunan dan komposit yang tersusun dari serat penguat yang tersusun secara acak yang biasa digunakan pada fabrikasi bodi kendaraan [13].

\section{TINJAUAN PUSTAKA}

Impact test atau pengujian tumbukan adalah salah satu cara mengetahui dan menganalisa sifat mekanik material, dalam hal ini ketangguhan material dan dalam penggunaannya dalam aplikasi teknik nantinya[10]. Pengujian impact adalah suatu pengujian yang digunakan untuk menentukan sifat suatu material yang mendapatkan beban dinamis, sehingga dari pengujian ini dapat diketahui sifat ketangguhan suatu material baik dalam wujud liat maupun ulet serta getas. Dengan catatan bahwa apabila nilai atau kekuatan impact semakin tinggi maka material tersebut memiliki keuletan yang tinggi. Nilai kekuatan impact pada suatu spesimen adalah energi yang diserap tiap satuan luas penampang lintang spesimen $\mathrm{uji}^{\left[{ }^{[11]}\right.}$. 


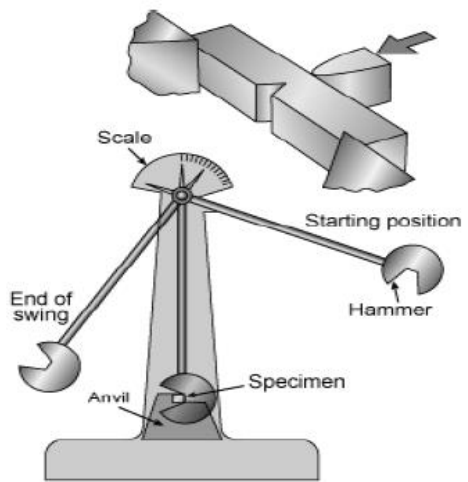

Gambar.1 . Ilustrasi uji impact metode charpy

Metode yang telah menjadi standar untuk uji impak ini ada 2, yaitu uji impak metode charpy dan metode izod[12]. Pada metode charpy pengujian tumbuk dilakukan dengan meletakan posisi spesimen uji pada tumpuan dengan posisi horizontal/mendatar, dan arah pembebanan berlawanan dengan arah tarikan[11]. Ilustrasi pengujian impact dengan metode charpy dapat di lihat pada Gambar.1.

Nilai energi yang diserap pengujian impact di didapat dengan melakukan perhitungan menggunakan rumus [12]:

$$
\begin{aligned}
& \text { Energi yang Diserap }(\mathrm{E}) \quad=\mathrm{Ep}-\mathrm{Em} \\
& =\mathrm{m} \cdot \mathrm{g} \cdot \mathrm{h}_{1}-\mathrm{m} \cdot \mathrm{g} \cdot \mathrm{h}_{2} \\
& =\mathrm{m} \cdot \mathrm{g}\left(\mathrm{h}_{1}-\mathrm{h}_{2}\right) \\
& =\mathrm{m} \cdot \mathrm{g}(\lambda(1-\cos \alpha)-\lambda(\cos \beta-\cos \alpha) \\
& =\mathbf{m} \cdot \mathbf{g} \cdot \boldsymbol{\lambda}(\cos \beta-\cos \alpha)
\end{aligned}
$$

Sedangkan untuk nilai kekuatan impact dilakukan perhitungan dengan menggunakan rumus :

Impact Strength (IS) $\quad=\underline{\mathrm{E}}$

$$
\begin{aligned}
& \frac{\mathrm{m} \cdot \mathrm{g} \cdot \lambda(\cos \beta-\cos \alpha)}{(\mathbf{a} \times \mathbf{b})}
\end{aligned}
$$

Keterangan :

$$
\begin{array}{ll}
\mathrm{Ep} & =\text { Energi Potensial } \\
\mathrm{Em} & =\text { Energi Mekanik } \\
\mathrm{m} & =\text { Berat Pendulum }(\mathrm{Kg}) \\
\mathrm{g} & =\text { Gravitasi } 9,81 \mathrm{~m} / \mathrm{s}^{2} \\
\mathrm{~h}_{1} & =\text { Jarak awal pendulum -benda uji (m) } \\
\mathrm{h}_{2} & =\text { Jarak akhir pendulum -benda uji (m) } \\
\lambda & =\text { Jarak lengan pengayun }(\mathrm{m})
\end{array}
$$

$\cos \alpha=$ Sudut posisi awal pendulum $\cos \beta=$ Sudut posisi akhir pendulum IS $=$ Nilai $\operatorname{Impact}\left(\mathrm{Kgm} / \mathrm{m}^{2}\right)$

$\mathrm{J} \quad=$ Energi yang diserap $(\mathrm{Kgm})$

A $\quad$ Luas penampang dibawah takikan $\left(\mathrm{m}^{2}\right)$

a $\quad=$ Tebal specimen dibawah takikan $\left(\mathrm{m}^{2}\right)$

$\mathrm{b} \quad=$ Lebar specimen dibawah takikan $\left(\mathrm{m}^{2}\right)$

\section{METODE}

Pada penelitian ini material yang digunakan adalah serat kaca, Resin Polyester (GP 500), dan katalis. Sedangkan alat yang dibutuhkan yaitu, timbangan, plat stainless steel, kuas, dan geraji. Pembuatan model bodi mobil listrik berbahan komposit serat kaca dikerjakan dengan beberapa tahap. Serat kaca dan resin ditimbang sesuai variasi komposisi fraksi berat yang telah ditentukan. 100 gr serat kaca, 270 gr resin dan $0,5 \mathrm{ml}$ disiapkan untuk membuat campuran komposit dengan perbandingan komposisi 1: 2,7 sedang 50 gr serat kaca, 220 gr resin dan 0,5 ml disiapkan untuk membuat campuran komposit dengan perbandingan komposisi 1: 4,4. Sejumlah serat yang telah disiapkan di atur susunan arahnya sesuai dengan variasi besar sudut yang telah ditentukan $\left(30^{\circ}, 45^{\circ}, 60^{\circ}\right.$, dan acak) pada plat stainless steel, seperti yang disajikan pada Gambar. 2. 


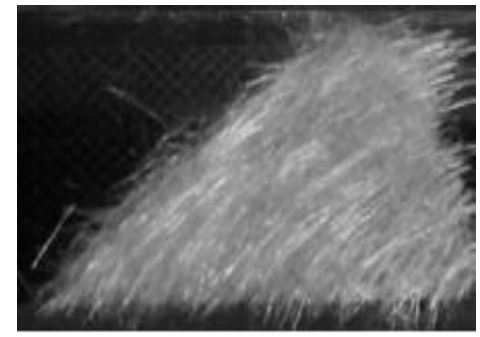

(a)

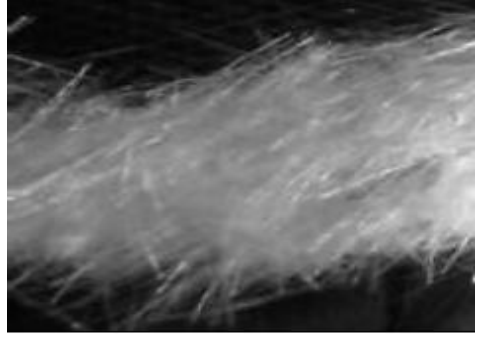

(b)

Gambar.2 . Susunan serat sudut seragam dengan sudut $45^{\circ}$ (a) dan susunan serat acak (b)

Besar sudut penyusunan serat kaca dihitung antara kemiringan serat dan sumbu y (ordinat). Setelah itu, resin dicampur dengan katalis dan dioleskan merata ke seluruh permukaan serat kaca dengan menggunakan kuas. Tanpa menunggu proses pemadatan cara sebelumnya diulangi sampai mencapai $95 \%$ dari ketebalan desain spesimen uji impact.

Memodelkan pembuatan bodi mobil listrik tipe prototype, lembaran komposit serat kaca yang telah memadat dipotong seperti desain spesimen uji impact, dihaluskan permukaannya dengan menggunakan kertas gosok grade 700 lalu di dempul agar permukaan yang dihasilkan pada specimen menjadi rata dan sesuai dengan ukuran yang diingikan pada desain spesimen uji impact.

Uji impact dilaksanakan dengan menggunakan spesimen uji berbentuk batang balok berdimensi panjang, lebar, dan tebal masing-masing 100, 10, $10 \mathrm{~mm}$. Sketsa spesimen impact seperti yang disajikan pada Gambar.3.(a), sedangkan spesimen impact siap uji dapat dilihat pada Gambar 3 (b).

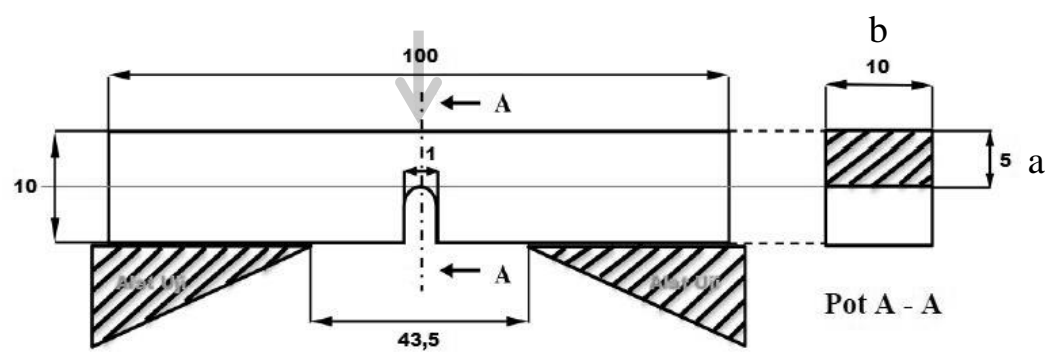

(a)

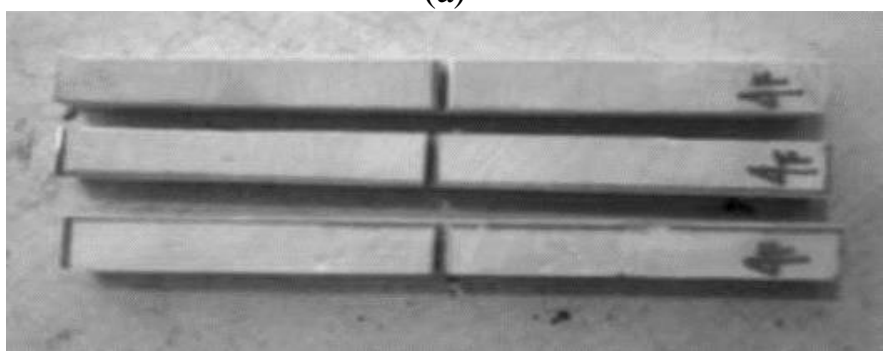

(b)

Gambar.3 . (a) Desain Spesimen Uji Impact (b) Spesimen Uji Impact siap uji

Spesimen uji impact bertakik berbentuk U (U Notch) dengan diameter lubang $1 \mathrm{~mm}$ dan dilaksanakan dengan metode charpy. Dilakukan 3 kali pengukuran dan pengulangan dalam setiap pengukuran atau pengujian untuk tiap specimen yang diuji.

\section{HASIL DAN PEMBAHASAN}

Kekuatan impact dinyatakan sebagai kemampuan material untuk menerima beban kejut/tibatiba. Dalam penelitian ini pengujian impact dilakukan untuk mengetahui kekuatan bodi prototipe mobil listrik yang akan di bangun dalam menerima beban kejut, sebagai simulasi pembebanan tibatiba yang mungkin diterima oleh bodi mobil pada saat berada di jalan raya, efek getaran yang 
dihasilkan oleh mesin dan sistem pengereman terhadap rangka mobil, dan kemungkinan terjadinya kecelakaan.

Dari pengujian impact didapat umpan balik berupa nilai sudut $\beta$, dengan nilai tersebut dan nilai berat pendulum dan panjang pendulum yang sudah diketahui dan merupakan karakteristik dari alat uji impact, yang diketahui berturut-turut sebesar 7,012 $\mathrm{Kg}$ dan $0.5502 \mathrm{~m}$. Maka dengan Persamaan (1), kita dapat menghitung besar energi yang dapat diserap oleh material yang dinyatakan dengan $\mathrm{E}$ dan menghitung nilai kekuatan impact yang dinyatakan dengan IS dengan menggunakan Persamaan (2). Dari perhitungan didapat nilai E dan nilai IS seperti yang tersaji pada Tabel 1. Dan Tabel 2. Tabel 1 memuat nilai E dan nilai IS untuk specimen dengan komposisi campuran komposit $1: 2,7$ sedangkan Tabel 2 memuat nilai $E$ dan nilai IS untuk specimen dengan komposisi campuran komposit $1: 4,4$. Gambar 4.(a) memuat perbandingan nilai rata-rata $\mathrm{E}$ secara grafik untuk komposit dengan perbandingan komposisi 1:2,7 dan 1:4,4 untuk masing masing orientasi, sedangkan Gambar 4 (b). menunjukkan perbandingan nilai rata-rata IS.

Tabel 1. Tabel Nilai E dan Nilai IS pada pengujian impact spesimen dengan perbandingan komposisi $1: 2,7$

\begin{tabular}{|c|c|c|c|c|c|c|}
\hline $\begin{array}{c}\text { Sudut } \\
\text { Orientasi }\end{array}$ & $\begin{array}{l}\text { Uji } \\
\text { Ke- }\end{array}$ & $\begin{array}{c}\text { Sudut } \beta \\
\quad\left({ }^{\circ}\right)\end{array}$ & $\begin{array}{c}\text { Nilai E } \\
(\text { kgm) }\end{array}$ & $\begin{array}{c}\text { Rata-Rata } \\
\text { Nilai E } \\
(\text { kgm) } \\
\end{array}$ & $\begin{array}{c}\text { Nilai IS } \\
\left(\mathbf{k g m m} / \mathbf{m}^{2}\right)\end{array}$ & $\begin{array}{c}\text { Rata-Rata } \\
\text { Nilai IS } \\
\left(\mathrm{kgmm} / \mathbf{m m}^{2}\right) \\
\end{array}$ \\
\hline \multirow{3}{*}{$30^{\circ}$} & 1 & 94 & 0.4 & 0.423 & 400 & 422.67 \\
\hline & 2 & 93 & 0.468 & \pm & 468 & \pm \\
\hline & 3 & 94 & 0.4 & 0.039 & 400 & 39.26 \\
\hline \multirow{3}{*}{$45^{\circ}$} & 1 & 96 & 0.266 & 0.311 & 266 & 310.67 \\
\hline & 2 & 95 & 0.333 & \pm & 333 & \pm \\
\hline & 3 & 95 & 0.333 & 0.039 & 333 & 38.68 \\
\hline \multirow{3}{*}{$60^{\circ}$} & 1 & 98 & 0.133 & 0.155 & 133 & 155.00 \\
\hline & 2 & 98 & 0.133 & \pm & 133 & \pm \\
\hline & 3 & 97 & 0.199 & 0.038 & 199 & 38.11 \\
\hline \multirow{3}{*}{ Acak } & 1 & 92 & 0.535 & 0.557 & 535 & 557.33 \\
\hline & 2 & 92 & 0.535 & \pm & 535 & \pm \\
\hline & 3 & 91 & 0.602 & 0.039 & 602 & 38.68 \\
\hline
\end{tabular}

Tabel 2. Tabel Nilai E dan Nilai IS pada pengujian impact spesimen dengan perbandingan komposisi $1: 4,4$

\begin{tabular}{|c|c|c|c|c|c|c|}
\hline $\begin{array}{c}\text { Sudut } \\
\text { Orientasi }\end{array}$ & $\begin{array}{l}\text { Uji } \\
\text { Ke- }\end{array}$ & $\begin{array}{c}\text { Sudut } \beta \\
\quad\left({ }^{\circ}\right)\end{array}$ & $\begin{array}{c}\text { Nilai E } \\
(\text { kgm) }\end{array}$ & $\begin{array}{c}\text { Rata-Rata } \\
\text { Nilai E } \\
\text { (kgm) }\end{array}$ & $\begin{array}{c}\text { Nilai IS } \\
\left(\mathbf{k g m} / \mathbf{m}^{2}\right)\end{array}$ & $\begin{array}{c}\text { Rata-Rata } \\
\text { Nilai IS } \\
\left(\mathrm{kgmm} / \mathrm{mm}^{2}\right)\end{array}$ \\
\hline \multirow{3}{*}{$30^{\circ}$} & 1 & 96 & 0.266 & 0.311 & 266 & 310.67 \\
\hline & 2 & 95 & 0.333 & \pm & 333 & \pm \\
\hline & 3 & 95 & 0.333 & 0.039 & 333 & 38.68 \\
\hline \multirow{3}{*}{$45^{\circ}$} & 1 & 97 & 0.199 & 0.221 & 199 & 221.33 \\
\hline & 2 & 97 & 0.199 & \pm & 199 & \pm \\
\hline & 3 & 96 & 0.266 & $0 . \overline{0} 39$ & 266 & 38.68 \\
\hline \multirow{3}{*}{$60^{\circ}$} & 1 & 99 & 0.066 & 0.111 & 66 & 110.67 \\
\hline & 2 & 98 & 0.133 & \pm & 133 & \pm \\
\hline & 3 & 98 & 0.133 & 0.039 & 133 & 38.68 \\
\hline \multirow{3}{*}{ Acak } & 1 & 94 & 0.4 & 0.400 & 400 & 400.00 \\
\hline & 2 & 94 & 0.4 & \pm & 400 & \pm \\
\hline & 3 & 94 & 0.4 & 0.0000 & 400 & 0.0000 \\
\hline
\end{tabular}



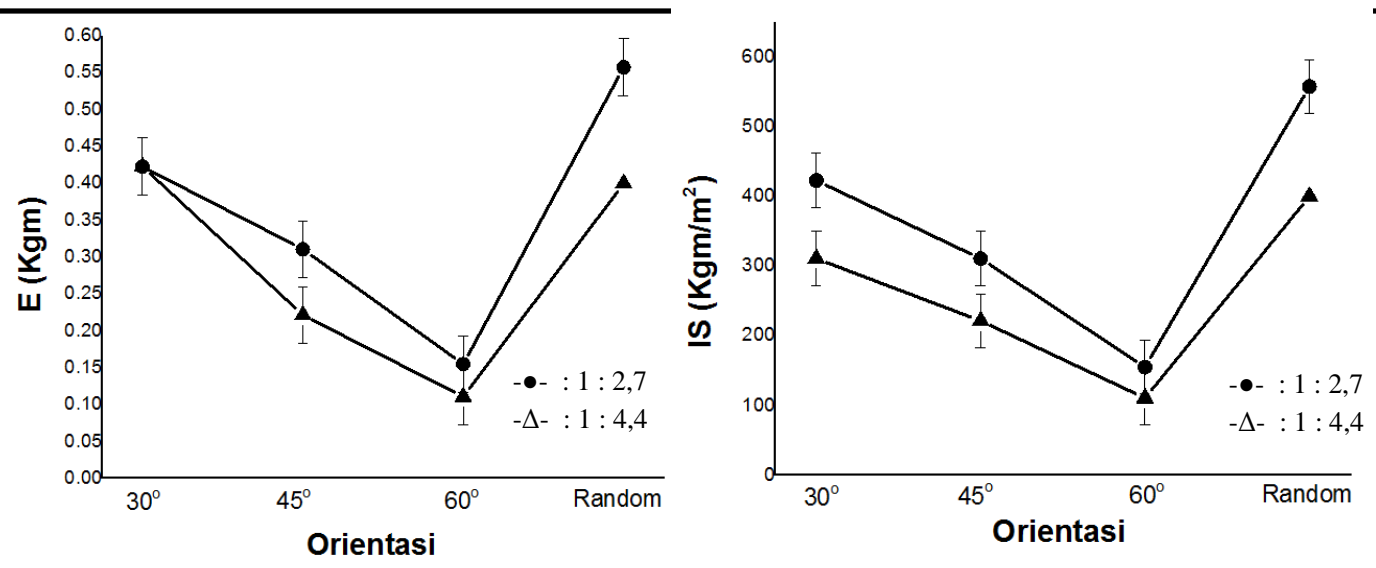

Gambar.4 (a) Nilai rata-rata E (b) Nilai rata-rata IS untuk komposit dengan perbandingan komposisi 1:2,7 dan 1:4,4

Hasil pengujian impact menunjukkan bahwa nilai kekuatan impact tertinggi pada semua variasi komposisi dihasilkan oleh susunan orientasi acak. Nilai tersebut meurpakan nilai kekuatan impact tertinggi dibandingkan dengan nilai yang didapat dari komposit yang tersusun secara seragam dengan variasi sudut di setiap komposisi campuran. Hal ini memungkinkan terjadi akibat sebaran variasi sudut serat yang tersusun yang mengakibatkan komposit menjadi material yang lebih tidak bersifat orthotropik. Disebutkan bahwa penyusunan serat secara uniaksial akan membuat material bersifat orthotropic[1]. Dimana material orthrotopik merupakan bagian dari material anisotropik yang memiliki sifat mekanik yang berbeda pada 3 sumbu utama orthogonal. Penyusunan serat yang seperti ditunjukkan pada ilustrasi Gambar.5 perihal penyusunan arah serat kaca, menunjukkan kesesuaian dengan hasil yang ditunjukkan pada perhitungan kekuatan impact pada specimen uji, dimana nilai kekuatan impact pada komposit yang disusun seragam dengan besar sudut $60^{\circ}$ menunjukkan nilai paling rendah. Hal ini dapat dijelaskan bahwa lapisan komposit ini memiliki sifat mekanik yang sangat rendah pada arah yg sejajar ketebalannya[9]. Disimpulkan juga bahwa nilai kekuatan impact akan meningkat dengan bertambahnya komposisi penambahan serat pada campuran komposit.

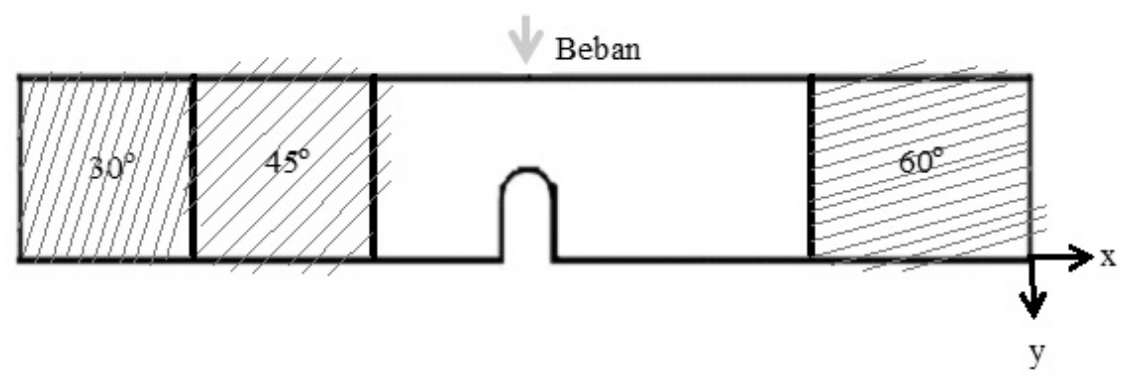

Gambar 5. Desain variasi susunan serat

\section{KESIMPULAN}

Pembuatan komposit serat kaca dengan penyusunan acak menggunakan komposisi campuran material penguat dan material pengikat $1: 2,7$ menghasilkan nilai kekuatan impact tertinggi, senilai $557.33 \pm 38.68 \mathrm{kgm} / \mathrm{m}^{2}$. Disetiap komposisi campuran komposit yang di variasikan, nilai kekuatan impact tertinggi selalu didapat dari penyusunan serat kaca secara acak. Didapatkan nilai yang berbeda signfikan $(\mathrm{P}<0.05)$ antara nilai kekuatan impact dari susunan komposit serat kaca secara acak dengan nilai kekuatan impact dari susunan komposit seragam dengan sudut susunan serat kaca yang divariasikan. Nilai kekuatan impact akan meningkat dengan bertambahnya komposisi penambahan serat pada campuran komposit. 


\section{DAFTAR PUSTAKA}

[1] Sulistijono. 2012. Mekanika Material Komposit. Edisi Pertama Surabaya. ITSpress

[2] Orifici AC, Herszberg I, Thomson RS. Review of methodologies for composite material modelling incorporating failure. Compos. Struct. 2008. 86(1-3): 194-210.

[3] António CC, Hoffbauer LN. From local to global importance measures of uncertainty propagation in composite structures.Compos. Struct. 2008. 85(3): 213-225.

[4] Eik M, Puttonen J, Herrmann H. The effect of approximation accuracy of the orientation distribution function on the elastic properties of short fibre reinforced composites. Compos. Struct. 2016. 148: 12-18.

[5] Swolfs Y, Verpoest I, Gorbatikh L. A review of input data and modelling assumptions in longitudinal strength models for unidirectional fibre-reinforced composites. Compos. Struct. 2016. 150: 153-172.

[6] Philippidis TP, Lekou DJ. Probabilistic failure prediction for FRP composite. Compos. Sci. Technol. 1998. 58(12): 1973-1982.

[7] Chen G, Bezold A, Broeckmann C, Weichert D. On the statistical determination of strength of random heterogeneous materials. Compos. Struct. 2016.149: 220-230.

[8] M.H. Zhang, L. Li, P. Paramasivam, Flexural toughness and impact resistance of steelfibre-reinforced lightweight concrete, Mag. Concr. Res. 56 (5) (2004) 251-262,

[9] M. K. Hossain, M.. Mahmudur R. Chowdhury, K. et al. Polymer Degradation and Stability .2014. 99

[10] Zuchry M. 2012. Pengaruh Temperatur dan Bentuk Takikan Terhadap Kekuatan Impak.Jurnal Teknik.14(1) : 18-21

[11] Lakhtin, Y. 1968. Engineering Physical Metallurgy . Moscow: Mir Pub Lishers.

[12] Dieter, George, E, 1988, Metalurgi Mekanik, Edisi ke 3, jilid 2, Jakarta : Erlangga.

[13] Haryono, Ahmad. 2011. Pemanfaatan Fiberglass Untuk Pembuatan Body Plastik Kendaraan. Majalah Online Politeknosains. Vol 10 (1). 
- halaman ini sengaja dikosongkan - 